\title{
Attractiveness of virtualization of information flow from the perspective of providers of accounting services in Poland
}

\section{Michat BARAN ${ }^{1}$}

The Jagiellonian University in Kraków, Institute of Economics, Finance and Management, Department of Organization and Management

\author{
KINGA BAUER ${ }^{2}$ \\ Cracow University of Economics, Department of Accounting
}

\begin{abstract}
One of the most popular forms of implementing accounting tasks (especially in the case of SMEs) is to outsource them to specialized external entities. Even though the range of these tasks is clearly defined by law, organizational and technical solutions may vary. One of the more significant trends in this area is progressive virtualization of the information flow which, among other things, allows for improved communication with customers. The article is part of these considerations. It presents the results of questionnaire research whose aim was to determine the attractiveness of virtualization of communication with customers and the need of providers of accounting services to modernize their IT systems. The study was conducted among 114 respondents from southern Poland. The results show that the attractiveness of virtualisation of accounting services is assessed at a relatively high level.
\end{abstract}

Paper type: research article

Keywords: outsourcing of accounting services, information management, information/IT systems, accounting, bookkeeping, virtualization of accounting services

1 michal.baran@uj.edu.pl

2 kinga.bauer@uek.krakow.pl 


\section{Introduction}

Accounting, which continues to be a major source of information on the financial health and business risk of a company, is constantly undergoing a process of evolution whose main purpose is development and advancement (Micherda, 2014, p. 193). The changes in accounting relate to both the standardization of the rules concerning recording of particular transactions (Krasodomska, 2010), and the way of collecting, presenting, archiving and transmitting data (Szymczyk-Madej \& Madej, 2012). The changes also relate to the accounting subsystem, that is, bookkeeping. According to Dobija (1999, p. 29), it is shaped by, in addition to other factors, the needs of business entities. Increasing needs regarding the speed of data acquisition involve the expectation that the delivery of information to the right place at a certain time will improve the efficiency of business operations (Dziekański, 2012). This approach influences the more and more widespread use of information systems and the Internet by accounting service providers, although scientific research emphasizes the need for their further development for accounting purposes.

Due to the lack of efficient accounting systems, attempts are being made to create partial solutions, especially adapted to virtual organizations (Buthelezi, Adigun, Ekabua, \& Iyilade, 2008; Jiang, Novales, Mathieu, Casson, Rogers, \& Gordon, 2011; Waldburger, Göhner, Reiser, Rodosek, \& Stiller, 2009). Organizations are more and more often forced to submit accounting information electronically, not just within the organization but also outside of it. They undertake such activities voluntarily in order to increase the efficiency of information flow. The implementation of these activities is facilitated through effective IT systems.

In the context of the above considerations, it was assumed that the virtualisation of financial information flow would be a beneficial phenomenon, which would increase the efficiency of the use of accounting information and thereby contribute to the development of enterprises. At the same time, these considerations are based on the belief that an effective IT system used in accounting is a positive factor for the ability to collect, process and use financial data.

The aim of this article is to examine the relationship between the assessment of the extension of electronic communication with customers (the attractiveness of virtualization of information flow) and the need to modernize the IT system. A special case, that is, outsourcing accounting services, has been selected for the study.

Empirical research was carried out in Poland in 2015 on the group of 114 accounting specialists. The opinions of the interested environment were collected as part of the survey. Next, the results of the study were statistically analyzed. The obtained results, presenting the conditioning, the attitude of the employees of the accounting offices, allow to assess the analyzed issue. 


\section{Information in the context of the specific challenges of outsourcing accounting services}

The economic value of information and all the processes connected with its management are an obvious and widely-analyzed matter (Czekaj, Ćwiklicki, \& Obora, 2010). In the modern world, in developed countries, one can talk about the information age. This resource has become key to achieving the goal of conducting business activity, which involves efficient and stable generation of profits. In this context, it is not surprising that many companies are abandoning activities strictly relating to production in favour of coordinating processes, creating value through the development of innovative ideas, concepts, organizational solutions (Sierotowicz, 2013). Such an approach creates the conditions for widening the sphere associated with the use of virtual space. Such tendencies affect more or less every aspect of the functioning of the company (Lichtarski, 2010), including fulfilment of documentation-accounting obligations. Consequently, this is a sphere of planned optimization, progressive professionalization, one of the possible effects of which is outsourcing (especially for smaller organizations with limited financial resources, staff) (Oleksyn, Bugaj, \& Stańczyk, 2014). Innovative ICT solutions emerging on the market, initially only offering new opportunities, are rapidly becoming a common standard effectively modifying the rules of market competition (Dziekoński, 2011). This also happens even in the very conservative sphere of activity of the organization, that is, the preparation of accounting records in the organization (or its subcontractor).

An accounting model which makes use of outsourcing-based solutions means consenting to certain restrictions. One of the biggest restrictions is the difficulty in ensuring the security and confidentiality of information. In addition, there is the need to ensure timely implementation of accounting activities. Extending the circulation of documents outside the formal framework of one organization creates potential "bottlenecks." There may also appear a "deaf-phone" phenomenon. As a consequence, the more quickly they need to provide the data they need, the greater the difficulty in taking care of their complexity and credibility. The cost of the information exchange system is an additional problem. Hence, there appears a well-known management dilemma of choosing a dimension that needs to be optimized: price, quality, or the response time of such a system. In the case of this specific sphere of accounting, i.e. bookkeeping, the choice of priorities looks different than in other areas (Rokita \& Kaszuba-Perz, 2012). Any information ordered by the information manager is usually intended to serve the internal needs of the organization, to support the decision-making process. On the other hand, in the analyzed case, what constitutes an additional burden is the fact that accounting information is used to provide data on demand of external entities having the necessary rights and applying legal sanctions if needed. Thus, at the level of management, the dilemma whether it is profitable to document some transactions ceases to exist, because it is a necessity. It is worth 
considering whether, based on what is available (taking into account obligatory requirements), one can also obtain useful information (Lipińska, 2012). It is difficult, however, to rely on the good will of an external subcontractor who takes care of the economy of their own actions. There are many more conditions to be considered. A classic look at information draws attention to a set of key parameters such as: timeliness, comprehensibility, reliability and verifiability of sources, precision, objectivity, reliability, completeness (Baran, 2008). It must be noted that these features can negatively affect each other by limiting the chances of reaching an optimal level simultaneously in all these dimensions. This is especially true when it comes to the timeliness of information in the context of the expected broad and comprehensive range of knowledge provided (Malara \& Rzęchowski, 2011) - although there is, of course, a risk of collecting excess data, thus reducing the possibility of their processing.

By accepting the assumption that external expectations of the environment determine the fundamental principles of accounting documentation, it is possible to indicate the minimum boundary effects of the implementation of such tasks. The implementation of accounting functions in the company is governed by the provisions of the law regarding the scope and organization, form and the need to comply with the timetable of the work resulting from strictly defined terms. Of course, there is still some margin of freedom in analyzing one's resources as expected by the management, in accordance with the place in the hierarchy, the challenges to be considered, etc. As in any other case for internal purposes, one can prepare additional summaries of arbitrarily chosen aggregation levels, track the dynamics of the ongoing processes and make use of what alternative indicators show. What helps resolve these types of dilemmas are more and more often the latest technological advances (Tadeusiewicz, 2010) but, of course, the complete reliance on information systems is a question of distant future.

The observed pressure of the environment on the speeding up of information and accounting processes, reduction, optimization of operating costs results in the widespread use of modern IT systems, but so far it has been a matter of free choice of the companies interested ( $($ asak, 2009). The latest trends indicate a change of situation, and technological progress has forced the use of certain solutions in a mandatory way (Okoń-Horodyńska, Wisła, \& Sierotowicz, 2013). This includes in particular the issue of virtualizing the circulation of accounting documents and solutions integrating a single entity with its administrative environment and suppliers or customers. This process gradually blurs the boundaries that strictly separate specific organizations, creating a complex network of collaborating and interdependent elements (Strojny \& Żmuda, 2005). Over the years, ICT has played an instrumental role in fulfilling the tasks assigned to accounting services. The next solution turned out to be a comfortable and willingly used but ultimately unnecessary tool of work. All duties could also be performed in the traditional way. However, the recent legislation, in certain cases, obliges them to send selected documents only by electronic means. This makes it necessary for some companies meeting certain criteria to take adaptive actions, buy modern technology, and get qualified staff. Awareness of the 
progressive professionalization of organizational solutions applied in the accounting area of business entities (including the development of cooperative relations in the outsourcing model) supported by technology, is an inspiration to seek patterns of behaviour in the new virtual reality (Budzanowska-Drzewiecka, 2012).

\section{Importance of technological advances in outsourcing accounting services}

Outsourcing accounting services is a particularly widespread phenomenon for SMEs. As empirical research indicates, in many cases it is the result of excessive, too laborious accounting solutions (Cebrowska, 2013, p. 9), or a lack of knowledge of accounting and the reluctance to do it on one's own (Juźwicka \& Zakrzewska-Bielawska, 2014, pp. 34-35). In spite of simplifications, for the smallest companies, the burden ratio per employee is very high (Osikowicz, 2015, p. 160). The study highlights the advantages of outsourcing, such as, the reduction of salaries and equipment costs, as well as access to specialist knowledge and technology (Świetla, 2014, p. 94).

Technological and technical facilities may affect the transfer of accounting tasks to accounting offices. Implementation of integrated management systems is a major investment and organizational effort for companies. Difficulties deepen a relatively low awareness of the employees of companies that implement them. Most companies use distributed systems for accounting, payroll calculation, fragmentary support for cost and financial settlements. These systems often come from different manufacturers, so their operation is hindered (Chomiak-Orsa, 2007).

However, according to Chojnacka (2007) who analyzes the flow of accounting documents from the point of view of operational management, the use of modern information technology in accounting improves the organization of document circulation in the company, reduces staff time and gives greater control over costs to the management. In her opinion, modern information technologies (including computer networks and electronic document management systems) are more and more often used in businesses to streamline the flow of accounting documents in an enterprise. There is a clear shift away from paper documents in favour of electronic ones.

While there is a tendency to increase the use of modern information technology in accounting in Poland, at the beginning of the $21^{\text {st }}$ century only half of small companies used computers in their business activity, and about one third had access to the Internet (Janiec, 2004). At the same time, virtual bookkeeping is one of the areas where outsourcing has developed at the fastest. This is due to the fact that accounting offices employ specialists and have the necessary accounting software, provide accounting services to business entities using IT systems and the Internet. It is also a significant facilitator for the outsourcer, who can, as part of virtual outsourcing, electronically provide the necessary information on business events (Dziembek \& Stępniak, 2003). 
The results of Matejun's (2010) follow-up study also confirm that the case of SME companies is a particularly popular solution for outsourcing of accounting and tax consulting, where they rely on regular external services from legitimate professional suppliers known as accounting offices or tax consulting firms. These activities are connected with the transfer of the risk of the aging of technology, the additional costs of investing in accounting information systems, the accounting office and facilitating access to accounting records.

The results of the study of Swietla (2014) show that in the case of outsourcing accounting services, there is a tendency to seek online accounting services. This also affects the functioning of traditional accounting offices, which more and more often offer access to their on-line systems and the ability to remotely transfer information. However, according to Jędruczyk (2014, p. 52), Internet collaboration, which reduces the financial information scarcity in an enterprise, requires both having the appropriate technical infrastructure and the ability to use information technology.

Looking from the perspective of accounting office employees, the development of Internet communication with customers and offices is positively evaluated by them. What dominates is the awareness of potential benefits of the analyzed phenomenon. The results of the study indicate the willingness of the environment concerned to make additional effort to implement even more advanced solutions. This creates the basis for efficient and effective development of virtual information exchange (Bauer \& Baran, 2015, pp. 128-134).

In turn, according to the research of Szymczyk-Madej (2014), conducted in 2005 and 2014, the areas of accounting information systems that have been improved relate to the development and use of information technology. Nadolna (2007, p. 226) concludes that "The development of outsourcing services in the field of accounting has become possible thanks to the application of the latest achievements of IT and telecommunication. The development of the Internet has created special opportunities in this area."

According to these studies, there are noticeable changes in the direction of the virtualization of the flow of financial information in Poland. In the opinion of theorists and practitioners, these changes are beneficial for organizations. Virtualization of information flows may involve the flow of information within an enterprise or serve to improve communication with other entities. Electronic communication with offices may be mandatory, but internal communication is a matter of voluntary choice. The development of voluntary communication can be influenced by the quality of the IT system used.

\section{Research methodology}

In the context of theoretical considerations and the results of previous research, it was decided to assess the virtualization of the provision of accounting services, which deals with selected aspects of the flow of financial information, focusing on 
electronic communication with customers and assessing their IT systems. In addition, what is also signalled is the issue of electronic communication of accounting service providers with offices which are the final recipients of processed information from the clients of accounting offices. This makes it possible to emphasize the interconnections within the system.

The purpose of the study was to evaluate the attractiveness of virtualization understood as extending the scope of electronic communications to customers by accounting service providers in the field of financial information flow. It has been decided to verify whether a more favourable assessment of virtualization of customer communication (extending its scope) involves the need to modernize existing IT systems.

It was decided to conduct the study with the use of an auditorium questionnaire with the use of the author's paper questionnaire.

The data were obtained in the study conducted in 2015 in southern Poland. The group of responders consisted of experienced accountants running independent accounting offices. These accountants raised their competences during a series of specialized trainings organized by the professional self-government (trainings included subsequent groups of self-government members). In total, 114 completed questionnaires were collected and they were then processed statistically.

The analysis of the structure of the examined group shows that relatively small entities were dominant (Figure 1).

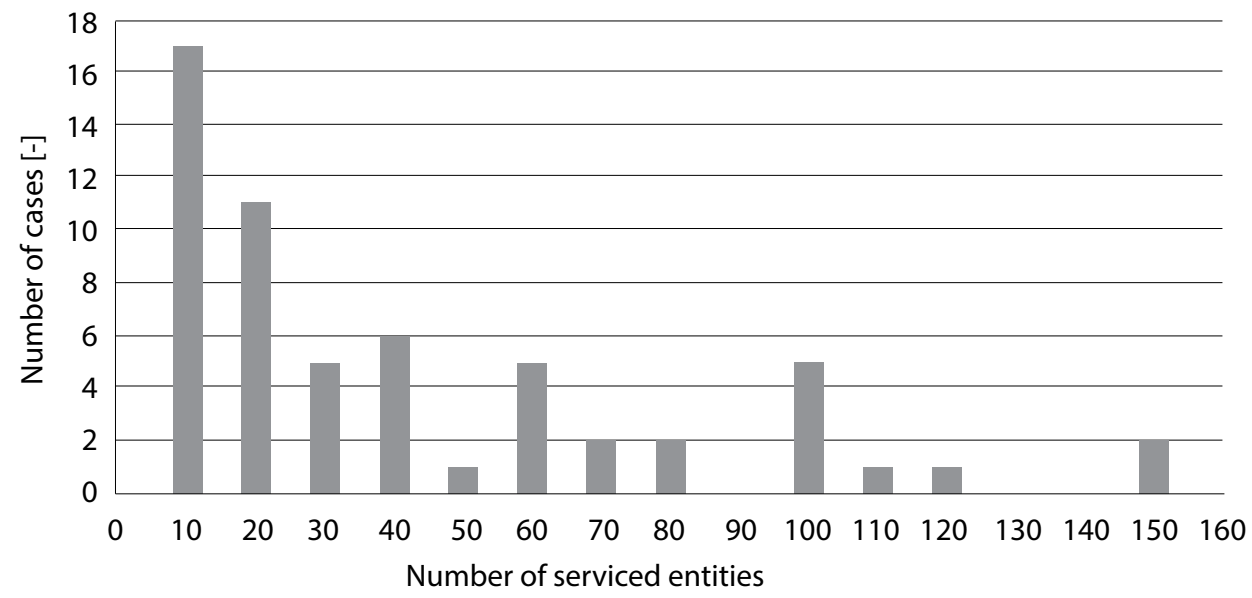

Figure 1. The structure of the surveyed accounting offices regarding the number of serviced entities $(n=58)$.

58 respondents (51\%) provided information on the number of serviced entities. These numbers vary from 1 to even 150 serviced entities $(m=40)$. The largest offices serving 140 to 150 entities were represented by only two cases. 


\section{Research results}

The data in Table 1 show the potential for extending the virtualisation of contacts between the examined accounting offices and their clients.

Table 1 Percentage of companies providing and able to provide electronic accounting data to the examined accounting offices in respondents' opinion

\begin{tabular}{|l|c|c|c|}
\hline Company category & $\begin{array}{c}\text { They deliver data electronically } \\
(\%)\end{array}$ & $\begin{array}{c}\text { They have the ability } \\
\text { to provide data } \\
\text { electronically (\%) }\end{array}$ & $\begin{array}{c}\text { Others } \\
\text { (\%) }\end{array}$ \\
\hline Micro & 22 & 37 & 41 \\
\hline Small & 25 & 47 & 28 \\
\hline Medium & 32 & 53 & 15 \\
\hline
\end{tabular}

* percentage calculated for each business category.

As the results show, despite the ability to provide data electronically, the use of this channel is relatively small, regardless of the size of the enterprise. This situation applies to all three analyzed categories of service recipients (micro, small, and medium). Therefore, even in the absence of additional investment, there is a chance of significantly raising the indicator examined.

Respondents assessed the extension of the scope of electronic communications with customers (Figure 2).

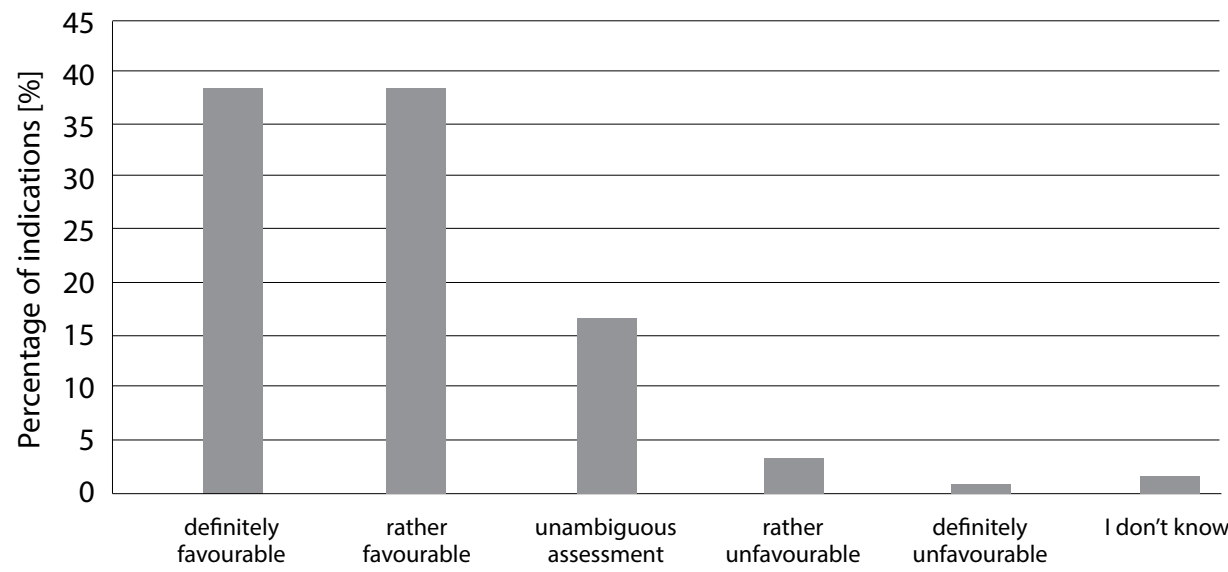

Assessment of the phenomenon of gradual widening of electronic communication

Figure 2. Assessment of the extension of electronic communication between the office and customers in the opinion of the respondents. 
The vast majority of respondents (as many as $77 \%$ or 87 respondents) perceive the benefits of extending electronic communications, and thus positively assesses the prospect of progressive virtualisation of the information flow in outsourcing accounting services. Only $5(4.5 \%)$ rated them as unfavourable (including one as very unfavourable).

What was also assessed was the need to modify information systems used for the electronic exchange of accounting documents (Figure 3).

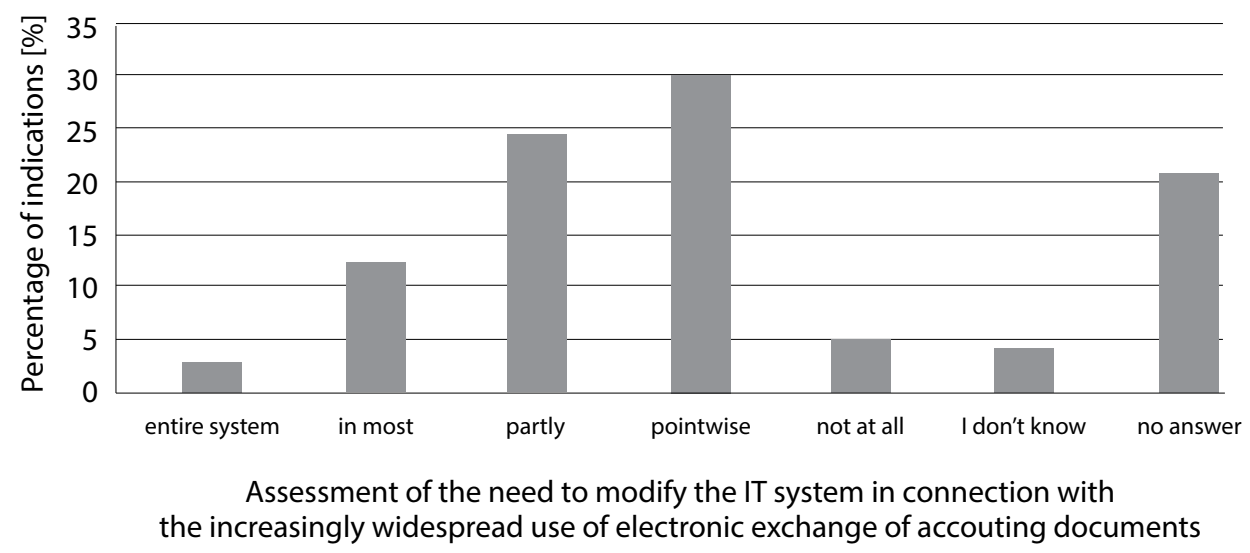

Figure 3. The scope of modifications of IT systems held by surveyed accounting offices in respondents' opinion.

Data show that a small group of respondents expect modifications of the entire system (3 people, 2.5\%), or most of its components (14 people, 12\%). Out of 114 respondents, 29 people $(25.5 \%)$ were unable to provide a binding response (including 5 answers I do not know). The largest group of respondents (34 people, 30\% of respondents) indicated the necessity of small modifications of IT systems in their offices (response pointwise).

The correlation between variables was tested using the Chi-square test, which showed a statistically significant relationship between the variables $(p=.05)$ (Table 2). However, low numbers of some indications should be noted, which makes it impossible to formulate conclusive claims.

A more detailed analysis was conducted and narrowed down to the answer of the respondents whose assessment was favourable and to some extension of the scope of electronic communication with customers. Three levels of modification of the IT system (mostly, partially, pointwise) were taken into account. There were 74 respondents (65\% of all respondents) whose answers were within the scope of possible answers, most of whom indicated the need for only pointwise and partial modification of the IT system used in the office (Figure 4). 
Table 2 Assessment of the virtualization of communication with customers depending on the perceived need to modify their IT systems

\begin{tabular}{|c|c|c|c|c|c|c|c|c|}
\hline \multirow{2}{*}{$\begin{array}{l}\text { Assessment of the } \\
\text { extension of electronic } \\
\text { communications }\end{array}$} & \multicolumn{8}{|c|}{ Need to modify IT systems } \\
\hline & No data & $\begin{array}{l}\text { Entire } \\
\text { system }\end{array}$ & In most & $\begin{array}{l}\text { Par- } \\
\text { tially }\end{array}$ & $\begin{array}{l}\text { Point- } \\
\text { wise }\end{array}$ & $\begin{array}{c}\text { Not at } \\
\text { all }\end{array}$ & $\begin{array}{l}\text { I don't } \\
\text { know }\end{array}$ & Total \\
\hline Definitely favourable & 9 & 2 & 7 & 4 & 15 & 5 & 2 & 44 \\
\hline Rather favourable & 10 & 0 & 4 & 17 & 12 & 1 & 0 & 44 \\
\hline Ambiguous assessment & 2 & 1 & 2 & 4 & 7 & 0 & 3 & 19 \\
\hline Rather unfavourable & 1 & 0 & 0 & 3 & 0 & 0 & 0 & 4 \\
\hline Definitely unfavourable & 0 & 0 & 1 & 0 & 0 & 0 & 0 & 1 \\
\hline I don't know & 2 & 0 & 0 & 0 & 0 & 0 & 0 & 2 \\
\hline Total & 24 & 3 & 14 & 28 & 34 & 6 & 5 & 114 \\
\hline
\end{tabular}

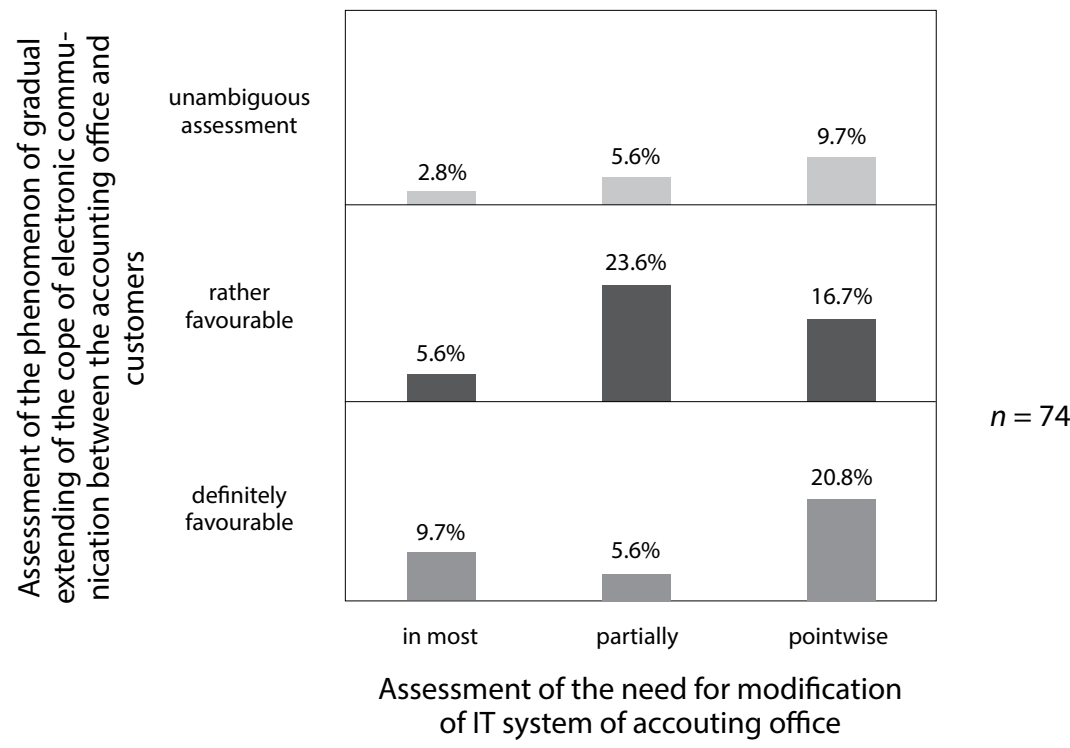

Figure 4. Assessment of the extension of electronic communications with customers according to the perceived need to modify the accounting office's IT system - a narrow analysis.

This may indicate that accounting offices when seeing the benefits of using electronic correspondence also see the need to modify their IT systems. They expect systematic improvement in their quality, but without revolutionary changes. They 
prefer to improve their existing IT systems, which may be due to the fact that they use proven software.

A similar comparison was made in the case of communication of accounting companies with offices. One can talk about obligatory and voluntary communications there.

In this case the numbers of some groups of indications were not satisfactory, so the indications of respondents who regarded extending the scope of electronic contacts as favourable (rather favourable and definitely favourable) were taken into account. Most of them indicated the need for pointwise, partial or major modifications of the IT system - both in the case of obligatory (Figure 5) and voluntary communication (Figure 6).
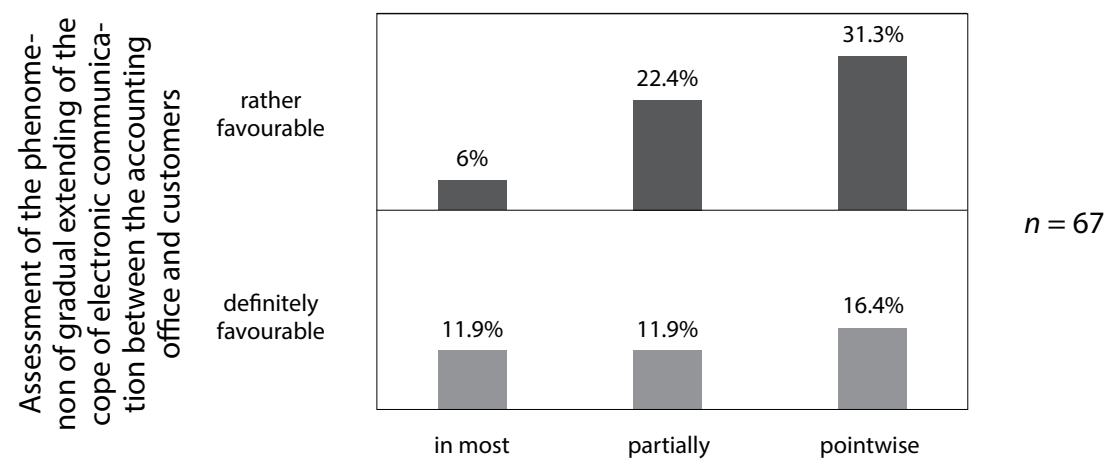

Assessment of the need for modification of IT system of accouting office

Figure 5. Assessment of the extension of electronic communications in the case of obligatory communication with offices depending on the perceived need to modify the accounting office's IT system - a narrow analysis.
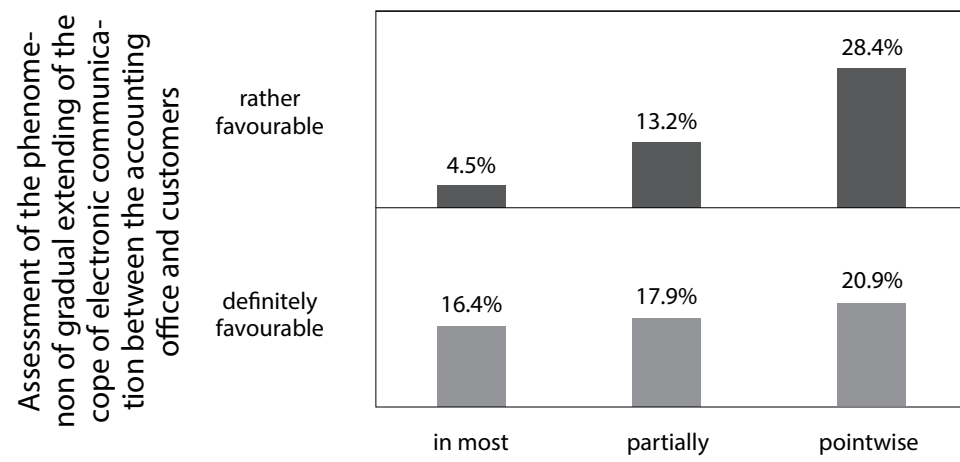

$$
n=67
$$

Assessment of the need for modification of IT system of accouting office

Figure 6. Assessment of the extension of electronic communication in the case of voluntary communication with offices according to the perceived need to modify the accounting office's IT system - a narrow analysis. 
In the case of obligatory communication, respondents who regard the extension of the scope of electronic communication with offices as definitely favourable have more varied expectations with respect to the extent of modifications to the IT system - percentage of indications of pointwise, partial and major changes - are similar to one another. On the other hand, among those who regard the extension of electronic contacts as rather favourable (nearly $60 \%$ of the indications) the indications of minor modifications of this system are dominant. A very similar distribution of responses was obtained in the case of voluntary communication, with the difference that there are many more people who are satisfied with the gradual extension of electronic communications with offices/authorities.

One can suggest that those who think it is a good idea to extend the scope of electronic communication with the offices/authorities are more critical in assessing the need to modify the IT system than those who are rather satisfied with the widespread use of electronic communication, indicating the need for pointwise modification only.

\section{Conclusions}

Over the centuries accounting has evolved together with changes in the economic environment. Various aspects of accounting have changed in the various stages of its development. The cause of these changes lies in the scientific, technical, economic and organizational progress. Economic, territorial, social and cultural transformations are also important (Sawicki, 2013). As literature and empirical studies have shown, the current trend of widespread use of the Internet for the transmission of information also influences accounting, with particular focus on outsourcing accounting services.

Based on the analyses conducted, it can be concluded that there is potential for further and effective virtualisation of the relationship between accounting offices and their clients in the outsourcing model.

The structure of the sample examined is marked by considerable fragmentation as accounting offices serving a small number of clients (from 1 to 10) dominate. This is a barrier in the case of the need to invest in the introduction of modern solutions supporting the virtualization of accounting documents circulation. Out of the observed phenomena, the positive attitude of accounting offices towards implementing these changes seems to be the most important. They perceive the benefits of making progress in this respect, so they can act as a spokesperson for changes to the businesses they serve.

Another issue relates to the technological solutions used. As far as customer groups are concerned, unused virtualization potential is based on hardware and

software that is already in use. Regarding the accounting offices only, the picture 
is no longer so clear, as the lack of necessary modifications in this case is signalled only by $5 \%$ of the respondents.

Because of the nature of the sample selected, the possibility of generalizing conclusions and relating them to the whole group of similar entities in Poland is limited. The size of the sample is not the only limitation. Another limitation of the study is collecting the opinion of only one of the stakeholders in the network of complex relationships that will influence the area of economic activity described. In the long term, one should deepen the analysis of the issue and collect the opinions of legislative representatives, clients of accounting offices and finally suppliers of information systems.

\section{References}

Baran, M. (2008). Informacja z perspektywy nauki organizacji i zarządzania. In L. Kiełtyka (ed.) Technologie i systemy komunikacji oraz zarządzania informacja $i$ wiedza. Warszawa: Difin, pp. 211-217.

Bauer, K., \& Baran, M. (2015). Virtualization of information as the direction of development of accounting support systems. Empirical evidence from Poland. International Journal of Accounting and Economics Studies, 3(2), 128-134.

Budzanowska-Drzewiecka, M. (2012). E-consumer behaviour as the basis for promotional activities on the Internet. In C. Sołek (ed.) Management Dilemmas in the Information Technology Era. Warszawa: Wydawnictwo Wojskowej Akademii Technicznej, pp. 177-186.

Buthelezi, M., Adigun, M.O., Ekabua, O.O., \& Iyilade, J. (2008). Accounting, pricing and charging service models for a GUISET grid-based service provisioning environment. In Proceedings of the 2008 International Conference on e-Learning, e-Business, Enterprise Information Systems, and e-Government, CSREA EEE, pp. 350-355.

Cebrowska, T. (2013). Kto i czego potrzebuje od rachunkowości małych i średnich przedsiębiorstw. Rachunkowość, (6), 9-11.

Chojnacka, A. (2007). Organizacja obiegu dokumentów księgowych a operacyjne zarządzanie przedsiębiorstwem. Prace Naukowe Akademii Ekonomicznej we Wrocławiu, (1150), 297305.

Chomiak-Orsa, I. (2007). Wykorzystanie nowoczesnych technologii w doskonaleniu procesów controllingowych. Prace Naukowe Akademii Ekonomicznej we Wrocławiu, (1150), 95-104.

Czekaj, J., Ćwiklicki, M., \& Obora, H. (2010). Ekonomika informacji v. infonomika. In R. Borowiecki, J. Czekaj (eds.) Zarządzanie zasobami informacyjnymi w warunkach nowej gospodarki, Warszawa: Difin, pp. 46-58.

Dobija, M. (1999). Rachunkowość zarządcza i controlling. Warszawa: Wydawnictwo Naukowe PWN.

Dziekański, P. (2012). Informacja jako dobro ekonomiczne będące źródłem przewagi konkurencyjnej. Nierówności Społeczne a Wzrost Gospodarczy, (24), 387-403.

Dziekoński, K. (2011). Projekty w innowacyjnych małych i średnich przedsiębiorstwach. Ekonomia i Zarządzanie, 3(4), 125-134.

Dziembek, D., \& Stępniak, C. (2003). Możliwości zastosowania wirtualnego outsourcingu w małych przedsiębiorstwach. Acta Universitatis Lodziensis, Folia Oeconomica, (167), 359-372. 
Janiec, M. (2004). Telekomunikacyjne bariery rozwoju Gospodarki Opartej na Wiedzy w Polsce, Instytut III Rzeczpospolitej.

Jędruczyk, E. (2014). Nowoczesne modele współpracy w outsourcingu usług księgowych i doradztwa podatkowego a wartość informacyjna ksiąg rachunkowych. Zeszyty Naukowe Uniwersytetu Szczecińskiego. Finanse. Rynki finansowe. Ubezpieczenia, (68), 45-54.

Jiang, M., Novales, C.D., Mathieu, G., Casson, J., Rogers, W., \& Gordon, J. (2011). An APEL tool based CPU usage accounting infrastructure for large scale computing grids. Data Driven e-Science. New York: Springer, pp. 175-186.

Juźwicka, A., \& Zakrzewska-Bielawska, A. (2014). Kompetencje pracowników a outsourcing służb finansowo-księgowych w małych przedsiębiorstwach. Zeszyty Naukowe Politechniki Łódzkiej. Organizacja i Zarządzanie, (1188; 57), 28-41.

Krasodomska, J. (2010). Anglosaski i kontynentalny model rachunkowości na przykładzie wybranych krajów. Zeszyty Teoretyczne Rachunkowości, 55(111), 119-137.

Lichtarski, J.M. (2010). Technologie informacyjne a kształt struktury organizacyjnej przedsiębiorstwa. Prace Naukowe Uniwersytetu Ekonomicznego we Wrocławiu. Informatyka Ekonomiczna, 17(118), 329-340.

Lipińska, A. (2012). Knowledge management of companies in the information society. Theory and practice. In C. Sołek (ed.) Management Dilemmas in the Information Technology Era. Warszawa: Wydawnictwo Wojskowej Akademii Technicznej, pp. 93-100.

Łasak, P. (2009). Wpływ asymetrii informacji na finansowanie przedsiębiorstw krajów wschodzących w dobie globalnego kryzysu - wybrane aspekty. Zeszyty Naukowe Wyższej Szkoły Zarzadzania i Finansów we Wrocławiu. Finanse i Rachunkowość, 28 (Studia Naukowe 1),197-216.

Malara, Z., \& Rzęchowski, J. (2011). Zarządzanie informacją na rynku globalnym. Teoria i praktyka. Warszawa: C.H. Beck.

Matejun, M. (2010). Outsourcing rachunkowości i doradztwa podatkowego w sektorze MSP implikacje dla urzędników skarbowych. In A. Adamik, M. Matejun, A. Zakrzewska-Bielawska (eds.), Problemy i wyzwania w zarządzaniu organizacjami publicznymi. Łódź: Wydawnictwo Politechniki Łódzkiej, pp. 276-299.

Micherda, B. (2014). Polityka rachunkowości w systemie rachunkowości. Studia Ekonomiczne, 201, 193-204.

Nadolna, B. (2007). Outsourcing. In K. Czubakowska (ed.) Od auditingu do sponsoringu w rachunkowości. Warszawa: Polskie Wydawnictwo Ekonomiczne, pp. 200-234.

Okoń-Horodyńska, E., Wisła, R., \& Sierotowicz, T. (2013). Leading trends of the information society technology development: case study of IBM. Transformations in Business \& Economics, 12(2B (29B)), 421-430.

Oleksyn, T., Bugaj, J., \& Stańczyk, I. (2014). Professional development in the five hundred largest Polish enterprises: Results of own research. In T. Marek, W. Karwowski, M. Frankowicz, J. Kantola, P. Zgaga (eds.) Human Factors of a Global Society: A System of Systems Perspective. Boca Raton, London, New York: CRC Press, Taylor \& Francis Group.

Osikowicz, M. (2015). Rachunkowość jednostek mikro według ustawy o rachunkowości. Research Papers of the Wroclaw University of Economics/Prace Naukowe Uniwersytetu Ekonomicznego we Wrocławiu, (388), 159-166.

Rokita, S., \& Kaszuba-Perz, A. (2012). Determinants of construction of information system which supports management of innovations. e-Finanse, 8, 53-63.

Sawicki, K. (2013). Zakres rachunkowości jako nauki. Zeszyty Teoretyczne Rachunkowości, (71), 211-226.

Sierotowicz, T. (2013). Koncepcje modeli biznesowych organizacji działających w wirtualnej przestrzeni życia gospodarczego. Zarzadzanie i Finanse, 11(1; v. 4), 455-466. 
Strojny, J., \& Żmuda, M. (2005). Wybrane determinanty kształtujące potencjał marketingowy i internetowy. In S. Ślusarczyk, R. Góra, J. Strojny (eds.), Internet a zarządzanie marketingowe Rzeszów: WSzIiZ, 125-156.

Szymczyk-Madej, K. (2014). Budowa i funkcjonowanie systemów informatycznych rachunkowości - porównanie wyników badań z lat 2005 i 2014. Prace Naukowe Uniwersytetu Ekonomicznego we Wrocławiu, (344), 520-530.

Szymczyk-Madej, K., \& Madej, J. (2012). Cechy systemu informatycznego rachunkowości. Prace Naukowe Uniwersytetu Ekonomicznego we Wrocławiu, (251), 476-487.

Świetla, K. (2014). Outsourcing usług księgowych w świetle oczekiwań biur rachunkowych i ich klientów. Zeszyty Naukowe Uniwersytetu Ekonomicznego w Krakowie. Seria Specjalna, Monografie, (231). Kraków: Wydawnictwo Uniwersytetu Ekonomicznego w Krakowie.

Tadeusiewicz, R. (2010). Place and role of intelligent systems in computer science. Computer Methods in Materials Science, 10(4), 93-206.

Waldburger, M., Göhner, M., Reiser, H., Rodosek, G.D., \& Stiller, B. (2009). Evaluation of an accounting model for dynamic virtual organizations. Journal of Grid Computing, 7(2), 181-204.

\section{Notes about the Authors}

Micha£ Baran - Ph.D. in Economics, Assistant Professor at the Department of Organization and Management of the Jagiellonian University in Kraków. The research activity of Michał Baran focuses primarily on the issues connected with information management and innovative application of IT systems in the organization.

Kinga Bauer - Ph.D. in Economics, Assistant Professor at the Department of Accounting of the Cracow University of Economics. She conducts research and publishes works on financial and management accounting, accounting of bankrupt companies and information management in the bankruptcy and recovery process. 